\title{
ДО МОДЕЛІ ВІДНОВЛЮВАЛЬНОГО ЛІКУВАННЯ ХВОРИХ НА ІШЕМІЧНУ ХВОРОБУ СЕРЦЯ ПІСЛЯ ХІРУРГІЧНОЇ РЕВАСКУЛЯРИЗАЦІЇ МІОКАРДА НА САНАТОРНОМУ ЕТАПІ
}

\section{๑О. В. Колоденко \\ ДУ «Український науково-дослідний інститут медичної реабілітації та курортології МОЗ України»}

РЕЗЮмЕ. В останнє десятиріччя в лікуванні ішемічної хвороби серця (IXC) набуло розвитку використання методів хірургічної реваскуляризації міокарда, які дозволяють суттєво ремоделювати міокард та значно покращити його функціональні властивості. Разом з тим, хірургічна реваскуляризація міокарда не усуває основних причин розвитку захворювань атеросклеротичної природи. Неефективно проведена реабілітація, включаючи недостатнє управління основними чинниками кардіоваскулярного ризику, може значно знизити результати виконаної операції.

Мета роботи - розробити модель відновлювального лікування хворих на IXC після хірургічної реваскуляризації міокарда з урахуванням коморбідної патології на санаторному етапі лікування.

Матеріал і методи. Методологія концептуальної моделі ґрунтується на визначені клініко-функціонального стану хворого та розрахунку інтегральної оцінки прогресування IXС у хворих, які перенесли ХРМ, з урахуванням функціональних та метаболічних показників, розробки індивідуальної програми санаторного лікування та визначення її ефективності.

Результати. Принцип побудови програм реабілітації повинен включати наступні блоки: мобілізація саногенетичних механізмів відновлення морфофункціонального стану міокарда, покращення психосоматичного стану хворих, підвищення фізичної працездатності; особливе місце в системі відновлювального лікування повинні займати технології, спрямовані на зниження ступенів ризику розвитку ускладнень як у перші дні після операційних втручань, так і в віддалені періоди.

Висновки. Диференційний підхід (залежно від коморбідної патології) до призначення комплексів відновлювального лікування сприяє підвищенню ефективності санаторно-курортного лікування на 44,4 \%.

КлючовІ СлОВА: ішемічна хвороба серця; відновлювальне лікування; хірургічна реваскуляризація; ефективність; модель санаторного лікування.

Вступ. Відновлювальне лікування (ВЛ), на популяційному рівні, це вид медичної допомоги, завдання якої полягає в формуванні стратегії з активної поведінки зі збереження, відновлення та зміцнення здоров' я населення, реалізації потенціалу здоров' я для ведення повноцінного професійного, соціального та особистого життя, зниження темпів старіння, передчасної смертності, захворюваності, інвалідизації населення та покращення демографічної ситуації в країні [1]. Досягнення цієї мети на індивідуальному рівні це насамперед активна зміна існуючого стереотипу поведінки, спрямована на відновлення психоемоційного стану та морфофункціональних змін серцево-судинної системи.

Особливої актуальності проблеми з реалізації програм ВЛ хворих на ішемічну хворобу серця (IXC) набувають у зв' язку з впровадженням методів хірургічної реваскуляризації міокарда (ХРМ). 3 одного боку, це пов'язано з тим, що оперативні втручання $\epsilon$ травматичними та потребують після операції мобілізації усіх компенсаторних можливостей організму, а з іншого - з відсутністю чітких критеріїв інтегральної оцінки характеру змін в організмі [2]. За даними багатьох авторів, стан післяопераційної дезадаптації кардіореспіраторної системи найвиразніше проявляється в ранні терміни та може зберігатися до 6 місяців після операції [3]. Окрім того, для післяопераційного періоду у хворих цієї категорії характерне формування особливих психологічних станів, які супроводжуються психоемоційними розладами, що може призводити до депресій та психосоціальної дезадаптації [4]. За цих умов дуже важливого значення набувають заходи щодо організації ВЛ у спеціалізованих центрах на базах санаторно-курортних закладів.

Враховуючи ці обставини, на думку багатьох авторів, при відсутності адекватного післяопераційного та наступного ВЛ значна частка пацієнтів працездатного віку не зможуть своєчасно повернутися до повноцінного трудового життя [5]. Вирішення питань щодо впровадження системи медичної реабілітації хворих після ХРМ натикається на ряд проблем, починаючи з розуміння патогенетичних механізмів розвитку ускладнень та ризику прогресування IXC, до визначення чітких критеріїв оцінки механізмів саногенетичних процесів при відновленні функціонального стану кардіореспіраторної системи. Відсутність на сьогодні спільної думки серед фахівців щодо характеру та напрямків психосоматичних змін у післяопераційний період хворих IXC з коморбідною патологією (цукровий діабет, артеріальна гіпертензія) стримує розвиток методичних підходів до розробки 
Огляди літератури, оригінальні дослідження, погляд на проблему

організаційних заходів побудови системи реабілітації та впровадження ефективних методів Вл.

Відсутність комплексних вітчизняних досліджень з обґрунтування оптимізації надання кардіологічної допомоги, з урахуванням сучасних світових вимог та рекомендацій, факторів ризику розвитку та особливостей перебігу IXC при коморбідній патології, обумовили актуальність даного дослідження, визначили його мету і завдання.

Мета роботи - створити модель системи ВЛ хворих на IXC після XРМ з урахуванням коморбідної патології на санаторному етапі лікування.

Матеріал і методи дослідження. Особливість методологічного підходу полягає в комплексній оцінці морфофункціонального, метаболічного та нервово-психічного стану хворих на IXC з коморбідною патологією після ХРМ з використанням показників інтегральної оцінки стану здоров'я та створення спільної команди впровадження програм ВЛ. Методична основа запропонованої нами моделі полягає в використанні принципів диференційних підходів до розробки програм ВЛ залежно від коморбідної патології. На нашу думку, саме цей принцип забезпечує необхідні умови переходу від існуючих загальнопопуляційних моделей до індивідуально-адаптованих програм лікування, а використання високоінформативних клінічних показників дозволяє забезпечити динамічне спостереження за психосоматичним станом цих хворих на всіх етапах ВЛ: стаціонарному, санаторнокурортному, амбулаторному.

При обґрунтуванні методологічних підходів до створення ефективної системи ВЛ хворих IXC після ХРМ ми опирались на фундаментальні принципи організації системи медичної допомоги [6]. Перш за все це медико-соціальна доцільність та ії доступність для населення, а також економічна ефективність та вмотивованість усіх учасників процесу.

3 огляду на ці принципи, у дослідження з о6ґрунтування концептуальних підходів до побудови системи ВЛ хворих на IXC з коморбідною патологією після ХРМ ми включили вивчення особливостей функціонального стану серцево-судинної системи, розробку інтегральної оцінки стану їх здоров'я та обґрунтування програми медичної реабілітації цих хворих з урахуванням супутньої патології.

Програма дослідження передбачала обстеження 280 хворих на IXC з супутньою патологією віком $(58,7 \pm 8,9)$ р. через 2-3 місяці після хірургічної реваскуляризації міокарда, які отримували стандартну медикаментозну терапію, а саме: нітрати, бета-блокатори, антагоністи кальцію, інгібітори ангіотензинперетворювального ферменту, дезагреганти, діуретики, гіполіпідемічні препарати, цукрознижувальні препарати та комплекс санаторно-курортної реабілітації.

Всі пацієнти контрольної групи ( $n=135)$ - хворі на IXC з супутньою патологією після XPM - були поділені на 3 підгрупи (підгрупа 1A - 45 хворих із супутньою артеріальною гіпертензією (АГ); підгрупа 1Б - 50 хворих із супутнім цукровим діабетом (ЦД); підгрупа 1В - 40 хворих із супутнім остеоартрозом). Програма лікування передбачала застосування стандартного комплексу санаторно-курортного лікування (режим рухової активності тренувальний, кліматотерапію (повітряні ванни за тренувальним режимом, сонячні ванни залежно від інтенсивності сонячної радіації), дієтотерапію, магнітотерапію сегментарних зон серця, масаж комірцевого відділу за гальмівною методикою, «сухі вуглекислі ванни») на тлі стандартної схеми медикаментозного лікування.

Програма пацієнтів основної групи (n=145) Хворі на IXC з супутньою патологією (підгрупа 2А - 48 хворих із супутньою АГ, підгрупа 2Б 55 хворих із супутнім ЦД, підгрупа B - 42 хворих із супутнім гонартрозом) - передбачала додаткове Включення диференційних комплексів ВЛ залежно від супутньої патології при:

- артеріальній гіпертензії - лазеротерапії та гідрокінезотерапії;

- цукровому діабеті - внутрішнього застосування маломінералізованої хлоридної натрієвої мінеральної води та гідрокінезотерапії;

- супутньому остеоартрозі - пелоїдотерапії та гідрокінезотерапії.

Курс лікування тривав 21 день.

Динаміку параметрів клінічного перебігу хвороби й оцінку ефективності проведеної терапії визначали до та після санаторно-курортного лікування. Алгоритм дослідження (до та після лікування) включав збір анамнезу, динамічне клінічне спостереження за об' єктивним і суб' єктивним станом пацієнтів, лабораторну діагностику (біохімічний аналіз крові, ліпідограма, цукор крові, інсулін, індекс НОМА, лептин) та інструментальні методи дослідження (ЕКГ, УЗД серця, холтерівське моніторування ЕКГ, вимірювання АТ, ЧСС, шестихвилинний тест (ТШХ)). Оцінку психологічного статусу проводили з використанням шкали HADS.

Для інтегральної оцінки стану хворих до та після відновлювального лікування розраховували запропонований нами інтегральний показник (I) та використовували метаболічні (лептин, індекс НОМА, індекс атерогенності), клініко-функціональні (індекс маси тіла (IMT), фізична працездатність та ФВ лівого шлуночка) та психологічні (визначення рівнів тривоги та депресії) показники [7].

Результати клінічних, інструментальних та лабораторних досліджень обробляли за загаль- 
Огляди літератури, оригінальні дослідження, погляд на проблему

ноприйнятими методами варіаційної статистики з використанням стандартної програми «Microsoft office-2000» та пакета стандартних статистичних програм «Statistica for Windows». Вірогідність відмінностей визначали за допомогою t-критерію Стьюдента (р). Для визначення наявності взаємозв' язку між двома ознаками використовували коефіцієнт кореляції (г) та відносності $\left(\chi^{2}\right)$.

Результати й обговорення. Комплексний підхід до вивчення психосоматичного стану хворих на IXC після XРМ дозволив відібрати найінформативніші показники оцінки морфофункціонального стану серцево-судинної системи. Як видно з даних, наведених у таблиці 1, високий рівень інформативності на етапі ВЛ мають показники рівня лептину в крові, далі - індекс атерогенності та індекс НОМА. За матеріалами експертної оцінки (метод
Дельфі) ми визначили значимість та провели ранжування кожного показника і запропонували методику розрахунку прогностичної системи оцінки психосоматичного стану хворих на IXC з коморбідною патологією після ХРМ на етапі ВЛ.

Інтегральний показник ступеня ризику прогресування IXC у цих хворих розраховували відповідно наведеної формули:

$$
\mathrm{I}=\frac{\sum a \mathrm{k}}{n}
$$

де $a$ - значення показника в балах, $k$ - ваговий коефіцієнт, $n$-кількість показників.

Цей інтегральний показник здоров'я дозволяє провести кількісну оцінку всіх якісних станів та ризиків для здоров'я пацієнтів за шкалою «низький», «критичний» та «високий».

Таблиця 1. Показники комплексної оцінки психосоматичного стану хворих IXC після ХРМ та критерії їх оцінки

\begin{tabular}{|c|c|c|c|c|}
\hline \multirow[b]{2}{*}{ Показники } & \multirow[b]{2}{*}{ Ваговий коефіцієнт } & \multicolumn{3}{|c|}{ Критерії } \\
\hline & & $\begin{array}{c}\text { низький } \\
\text { (1 бал) }\end{array}$ & $\begin{array}{c}\text { критичний } \\
\text { (2 бали) }\end{array}$ & $\begin{array}{l}\text { високий } \\
\text { (3 бали) }\end{array}$ \\
\hline Рівень лептину, мкг/л & 0,20 & $\leq 18,55$ & $18,55-20,69$ & $\geq 20,69$ \\
\hline Індекс атерогенності & 0,17 & $\leq 4,36$ & $4,36-5,21$ & $\geq 5,21$ \\
\hline Індекс НОМА & 0,09 & $\leq 4,6$ & $4,6-10,9$ & $\geq 10,9$ \\
\hline IMT кг/M² & 0,09 & $\leq 23,1$ & $23,1-34,4$ & $\geq 34,4$ \\
\hline Фізична працездатність (ТШХ) & 0,08 & $\geq 310$ & $310-265$ & $\leq 265$ \\
\hline$\Phi B, \%$ & 0,11 & $\geq 68,1$ & $55,3-68,1$ & $\leq 55,3$ \\
\hline Тривога (за шкалою HADS), бали & 0,13 & $0-7$ & $8-10$ & $\geq 11$ \\
\hline Депресія (за шкалою HADS), бали & 0,13 & $0-7$ & $8-10$ & $\geq 11$ \\
\hline
\end{tabular}

Такий підхід дозволяє значно підвищити інформативність запропонованих нами показників, підвищити їх наочність і створити передумови для розробки прогностичної системи з динамічного спостереження за станом хворих на всіх етапах ВЛ.

Незважаючи на високий кардіоваскулярний ризик ускладнень, у всіх хворих до початку ВЛ нами не встановлено суттєвих відмінностей щодо функціонального стану міокарда (ФВ лівого шлуночка була низькою у всіх хворих). При цьому загальний психосоматичний стан та виразність метаболічних порушень суттєво відрізнялися залежно від характеру супутньої патології.

При комплексній оцінці стану здоров'я пацієнтів до ВЛ з використанням інтегрального показника ми не встановили суттєвих відмінності в обох групах. В основній групі пацієнтів до початку ВЛ цей показник був на рівні 0,67, а в контрольній - 0,66. Після проведеного комплексу ВЛ у пацієнтів обох груп ми спостерігали покращення, але більш вірогідне зниження I на $44,4 \%$ було в другій групі $(p<0,01)$, тоді як у першій - лише на $18,5 \%$ ( $p \leq 0,05)$ (рис. 1).

3 огляду на те, що стан серцево-судинної системи хворих на IXC після відновлення гемодина- міки в коронарних судинах серця залежить не тільки від ефективності застосованих хірургічних технологій, а й від характеру супутньої патології, побудова системи ґрунтувалася на принципах диференційного підходу при обґрунтуванні програм ВЛ. Доцільність саме диференційного підходу базується на особливостях психосоматичного стану цих хворих, які визначаються характером патологічних змін в організмі за рахунок коморбідної патології (в нашому випадку АГ, ЦД, ОА).

Індивідуальний принцип побудови програм реабілітації повинен включати наступні блоки: мобілізація саногенетичних механізмів відновлення морфофункціонального стану міокарда, покращення психосоматичного стану хворих та підвищення фізичної працездатності (рис. 1). Особливе місце в системі відновлювального лікування повинні займати і технології, спрямовані на зниження ступенів ризику розвитку ускладнень як у перші дні після оперативних втручань, так і в віддалені періоди. На нашу думку, саме диференційний підхід може забезпечити гармонізацію сукупності медичних технологій відновлювального лікування до функціональних можливостей організму хворих. 
Огляди літератури, оригінальні дослідження, погляд на проблему

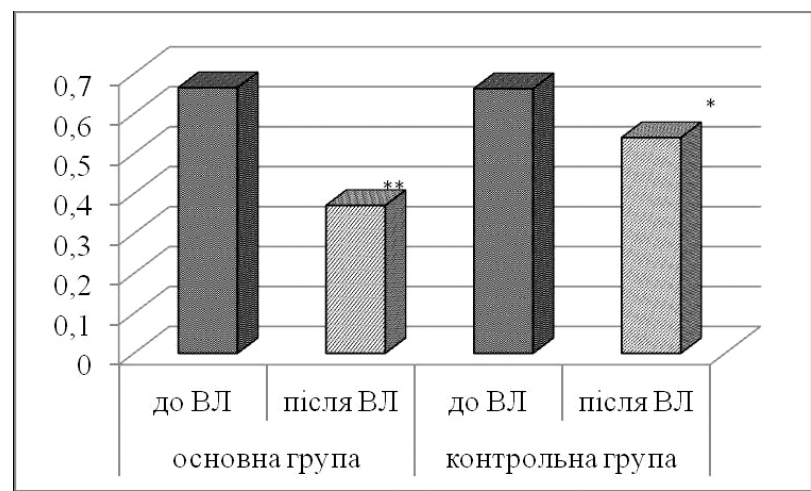

Примітка. * - різниця показників вірогідна, $\mathrm{p}<0,05 ; * *$ - різниця показників вірогідна, $\mathrm{p}<0,01$.

Рис. 1. Динаміка інтегральної оцінки хворих на IXC після XРМ на етапі відновлювального лікування.

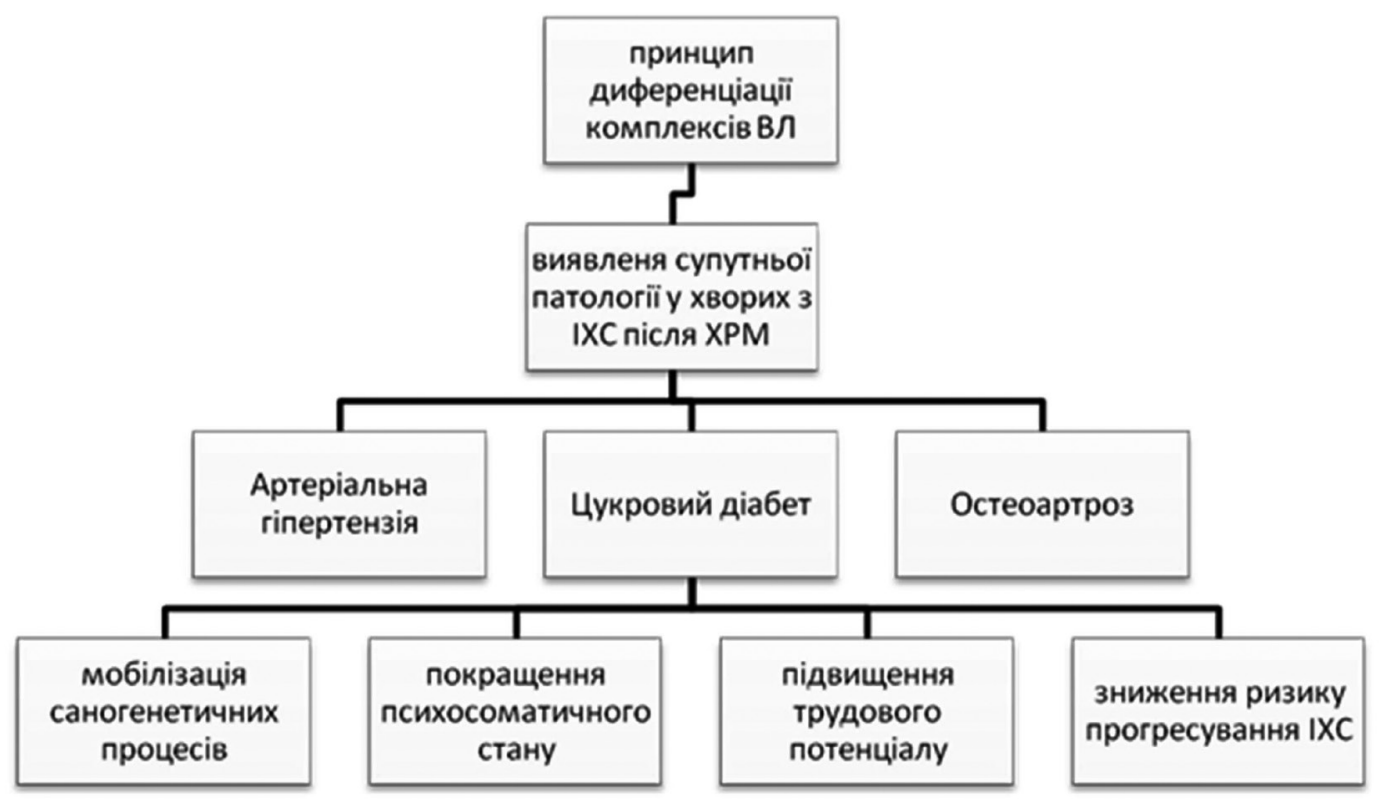

Рис. 2. Принципи диференціювання системи відновлювального лікування хворих на IXC залежно від характеру коморбідної патології.

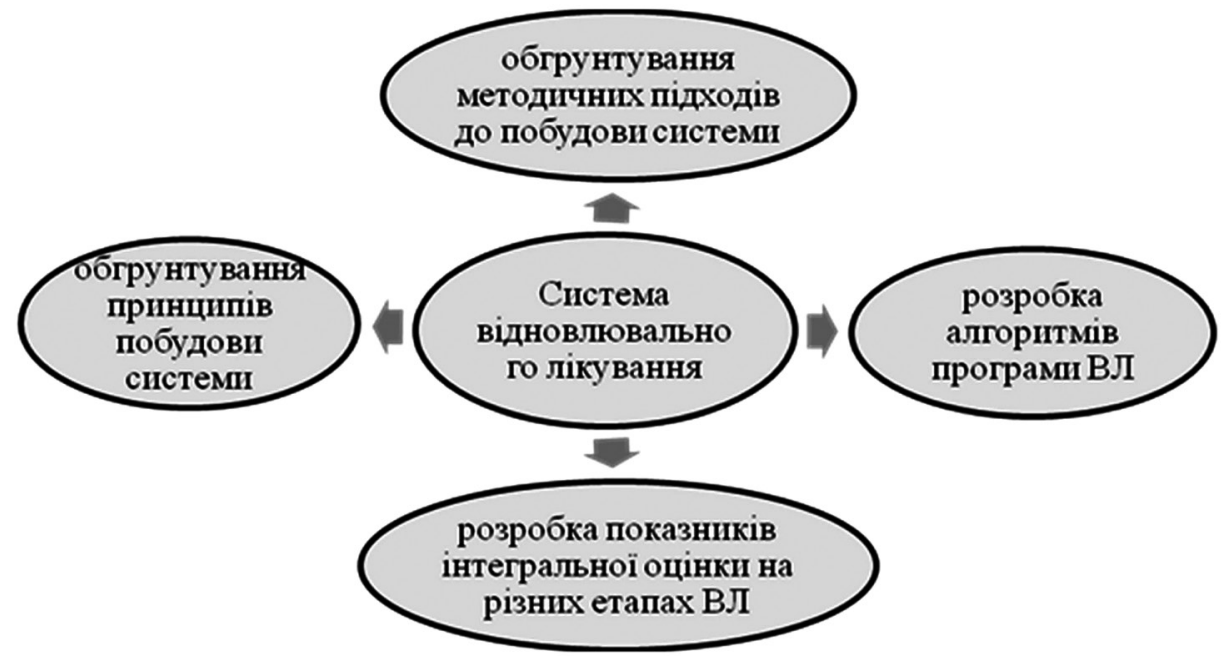

Рис. 3. Модель побудови системи відновлювального лікування. 
Огляди літератури, оригінальні дослідження, погляд на проблему

Запропонована нами концептуальна модель організації системи відновлювального лікування хворих на IXC з коморбідною патологією після хірургічної реваскуляризації міокарда об'єднує 4 основні блоки системи. Насамперед це обґрунтування принципів її розбудови та формування методичних підходів до розробки медичних технологій комплексного впливу на організм хворих. По друге, розробку алгоритмів побудови програм відновлювального лікування цієї категорії хворих та інформаційної системи на базі інтегральних показників оцінки психосоматичного стану хворих на різних етапах їх лікування (рис. 3).

На нашу думку, такий підхід забезпечує наступність на всіх етапах лікування та уніфікацію методів оцінки стану здоров' я пацієнтів при організації ВЛ.

Диференційний підхід з використанням інтегральних методів оцінки здоров'я дозволяє проводити наукове обґрунтування заходів щодо розробки індивідуальних програм реабілітації, а запропонований нами принцип «процесного підходу», який складає основу сучасної міжнародної системи оцінки якості послуг (ISO 9000-2015), дозволяє при їх розробці скоординувати заходи з відновлення метаболічних процесів у травмованих органах (клінічний етап) та технології відновлювального лікування (санаторний етап) для покращення психосоматичного стану пацієнтів. Саме такий алгоритм розробки програм ВЛ дозволяє домогтися ефекту потенціювання саногенетичних

\section{ЛITЕРАТУРА}

1. International Classification of Impairment, Disabilities and Handicaps. - Geneva: WHO, 1980, P. 206-207.

2. Бокерия, Л.А. Сердечно-сосудистая хирургия / J. А. Бокерия, Р. Г. Гудкова / НЦССХ.-М. :Б. и., 2007.-118 с.

3. European guidelines on cardiovascular disease prevention in clinical practice (version 2012) // J. Perk, G. de Backer, H., Gohlke [et al.] // Eur. Heart J. - 2012. - Vol. 33. P. 1635-1701.

4. Дукельський О. О. Депресія у хворих з ішемічною хворобою серця, які перенесли стентування коронарних артерій / О. О. Дукельський // Український вісник психоневрології. - 2010.- Т. 18, Вип. 4 (65). - С. 74-78.

\section{REFERENCES}

1. International Classification of Impairment, Disabilities and Handicaps. (1980). Geneva: WHO 206-207.

2. Bokeriya, L.A., \& Gudkova, R. (2007). Serdechnososudistaya khirurgiya [Cardiovascular surgery]. Moscow: NTSSSKH [in Russian].

3. Perk, J., de Backer, G., Gohlke, H., Graham, I., Reiner, Z., Verschuren, W.M. et al. (2012). European guidelines on cardiovascular disease prevention in clinical practice (version 2012). Eur. Heart J., 33, 1635-1701. механізмів відновлення функціональних та соціально-трудових можливостей організму.

Окрім того, запропонований нами алгоритм побудови індивідуальних програм ВЛ, з одного боку, створює хороші передумови до формування командного підходу (кардіохірург - лікар-реабілітолог - сімейний лікар), а з іншого - дозволяє значно підвищити ефективність соціально-економічної складової системи відновлювального лікування.

Висновки. 1. Існуюча система відновлювального лікування хворих як невід'ємна частина комплексного лікування Хворих на IXC з коморбідною патологією після ХРМ не повною мірою враховує особливості стану хворих, організаційні можливості закладів медичної реабілітації та принципи організації етапної медичної допомоги.

2. Практичне значення запропонованих нами методологічних підходів до обґрунтування алгоритмів організації ВЛ хворих на IXC після XРМ полягає в використані принципів «процесного підходу", на яких побудована міжнародна система «Менеджмент якості послуг ISO 9000-2015», що дозволяє забезпечити синергічний ефект медичних технологій ВЛ.

3. Диференційний підхід (залежно від коморбідної патології) при використанні програм ВЛ дозволяє максимально активізувати саногенетичні можливості організму, що дозволить значно підвищити ефективність санаторно-курортного лікування (понад 44,4\%).

5. Востриков В. Е. Реабилитация больных ИБС после АКШ на санаторном этапе : методические рекомендации / В. Е. Востриков, В. И. Зубкова, М. С. Шумкина. М., 2000. - C. 42-43.

6. Оганов Р.Г. Профилактическая кардиология: надежды и реальность / Р. Г. Оганов // Здравоохранение. - 2012. - № 9. - С. 60-67.

7. Kolodenko O. Integral evaluation of effectiveness of the renewal treatment of patients with ischemic heart disease after myocardium surgical revascularization / O. Kolodenko, V. Kolodenko, K. Babov // Eureka: Health Sciences. - 2017. - No. 5. - P. 11-15.

4. Dukelskyi, O.O. (2010). Depresiia u khvorykh z ishemichnoiu khvoroboiu sertsia, yaki perenesly stentuvannia koronarnykh arterii [Depression in patients with ischemic heart disease who have suffered coronary artery stenting]. Ukrainskyi visnyk psykhonevrolohii - Ukrainian Journal of Psychoneurology, 18, 4 (65), 74-78 [in Ukrainian].

5. Vostrikov, V.E., Zubkova, V.I., \& Shumkina M.S. (2000). Reabilitatsyya bolnykh IBS posle AKSh na sanatornom étape: Metodicheskie rekomendatsyi [Rehabilitation of 
Огляди літератури, оригінальні дослідження, погляд на проблему

patients with coronary heart disease after $C A B G$ at the sanatorium stage: Methodical recommendations]. Moscow [in Russian].

6. Oganov, R.H. (2012). Profilakticheskaya kardiologiya: nadezhdy i realnost [Preventive cardiology: hope and reality]. Zdravookhraneniye - Healthcare, 9, 60-67 [in Russian].
7. Kolodenko, O., Kolodenko, V., \& Babov, K. (2017). Integral evaluation of effectiveness of the renewal treatment of patients with ischemic heart disease after myocardium surgical revascularization. Eureka: Health Sciences, 5, $11-15$.

\title{
К МОДЕЛИ ВОССТАНОВИТЕЛЬНОГО ЛЕЧЕНИЯ БОЛЬНЫХ ИШЕМИЧЕСКОЙ БОЛЕЗНЬЮ СЕРДЦА ПОСЛЕ ХИРУРГИЧЕСКОЙ РЕВАСКУЛЯРИЗАЦИИ МИОКАРДА HА САНАТОРНОМ ЭТАПЕ
}

๑А. В. Колоденко

\author{
ГУ «Украинский научно-исследовательский институт медицинской реабилитации и курортологии \\ МЗ Украины»
}

РЕЗЮМЕ. В последнее десятилетие широкое развитие получили методы хирургической реваскуляризации миокарда (ХРМ), которые позволяют существенно улучшить кроовообращение миокарда и его функциональные свойства. Вместе с тем, ХРМ не устраняет основных причин развития заболеваний атеросклеротической природы. Неэффективно проведенная реабилитация, включая недостаточное управление основными факторами кардиоваскулярного риска, может значительно снизить результаты выполненной операции.

Цель работы - разработать модель восстановительного лечения больных ИБС после ХРМ с учетом коморбидной патологии на санаторном этапе лечения.

Материал и методы. Методология концептуальной модели основывается на определении клинико-функционального состояния больного и расчете интегральной оценки прогрессирования ИБС у пациентов, перенесших хирургическую реваскуляризацию миокарда, с учетом функциональных и метаболических показателей, разработки индивидуальной программы санаторного лечения и определения ее эффективности

Результаты. Принцип построения программ реабилитации должен включать следующие блоки: мобилизация саногенетических механизмов восстановления морфофункционального состояния миокарда, улучшение психосоматического состояния больных, повышение физической работоспособности; особое место в системе восстановительного лечения должны занимать технологии, направленные на снижение степени риска развития осложнений как в первые дни после оперативных вмешательств, так и в отдаленные периоды.

Выводы. Дифференцированный подход (в зависимости от коморбидной патологии) к назначению комплексов восстановительного лечения способствует повышению эффективности санаторно-курортного лечения на $44,4 \%$.

КЛЮчЕВЫЕ СЛОВА: ишемическая болезнь сердца; восстановительное лечение; хирургическая реваскуляризация миокарда; эффективность; модель санаторного лечения.

\section{TO THE MODEL OF RECOVERING TREATMENT OF PATIENTS WITH ISCHEMIC HEART DISEASE AFTER SURGICAL REVASCULARIZATION OF MYOCARDIUM ON SENSORY STAGE}

๑O. V. Kolodenko

\section{Ukrainian Research Institute of Medical Rehabilitation and Resorts of the Ministry of Health of Ukraine}

SUMMARY. In the last decade, the methods of surgical revascularization of the myocardium in treatment of coronary heart diseases (CHD) have been developed, which allow to substantially remodel the myocardium and significantly improve its functional properties. However, surgical revascularization of the myocardium does not eliminate the main causes of the development of diseases of atherosclerotic nature. Ineffective rehabilitation, including inadequate management of the main factors of cardiovascular risk, can significantly reduce the results of the performed operation.

The aim of the work - to develop a model of restorative treatment of patients with CHD after surgical revascularization (SR) of the myocardium taking into account the comorbidity of the pathology at the sanatorium treatment stage.

Materials and Methods. The methodology of the conceptual model is based on the definite clinical and functional status of the patient and the calculation of the integral assessment of CHD progression in patients who have undergone SRM taking into account functional and metabolic parameters, the development of an individual program of renewal treatment and its effectiveness determination.

Results. The principle of constructing rehabilitation programs should include the following blocks: mobilization of sanogenetic mechanisms of restoration of the morphofunctional state of the myocardium, improvement of the psychosomatic state of patients and increase of physical capacity and a special place in the system of rehabilitation should take technologies aimed at reducing the risk of complications in the first days after the operative interventions, and in distant periods

Conclusions. Differentiated approach (depending on the comorbid pathology) to the appointment of restorative treatment complexes contributes to improving the efficiency of sanatorium and renewal treatment by $44.4 \%$.

KEY WORDS: ischemic heart disease; renewal treatment; surgical revascularization; efficacy; model of sanatorium treatment.

Отримано 18.10.2017 